\title{
Pemanfaatan Protein Ransum pada Ayam Broiler yang Dipelihara pada Tingkat Kandang Kepadatan Tinggi
}

\section{(Broiler Chickens Protein Utilization Maintained at High Stocking Density)}

\author{
Robertus Septian Randy Pratama, Teysar AdiSarjana, \\ Edjeng Suprijatna, U Atmomarsono \\ Program Studi S1 Peternakan.
}

Fakultas Peternakan dan Pertanian Universitas Diponegoro

JI. Prof. Soedarto, SH. Tembalang, Semarang 1269, Jawa Tengan

Email:teysaradi@undip.ac.id

Diterima : 8 Februari 2019

Disetujui : 25 Mei 2019

\section{ABSTRAK}

Penelitian ini bertujuan untuk mengevaluasi pemanfaatan protein ransum pada ayam broiler yang dipelihara dalam kandang kepadatan tinggi. Materi yang digunakan dalam penelitian adalah ayam broiler sebanyak 280 ekor umur 15 hari dengan bobot badan rata-rata $298,37 \pm 23,33 \mathrm{~g}$. Rancangan acak lengkap (RAL) digunakan pada penelitian ini dengan 4 perlakuan dan 5 ulangan. Perlakuan yang diberikan yaitu $T 1=$ kepadatan kandang $8 \mathrm{ekor} / \mathrm{m}^{2}, \mathrm{~T} 2=$ kepadatan kandang $12 \mathrm{ekor} / \mathrm{m}^{2}, \mathrm{~T} 3=$ kepadatan kandang $16 \mathrm{ekor} / \mathrm{m}^{2}$ dan $\mathrm{T} 4=$ kepadatan kandang $20 \mathrm{ekor} / \mathrm{m}^{2}$. Parameter penelitian terdiri dari konsumsi protein, kecernaan protein, dan retensi nitrogen. Hasil penelitian menunjukkan bahwa semakin tinggi kepadatan kandang berpengaruh nyata menurunkan konsumsi protein $(P<0,05)$ tanpa mempengaruhi kecernaan protein dan retensi nitrogen. Disimpulkan bahwa peningkatan kepadatan kandang tinggi dapat menurunkan konsumsi protein tetapi tidak berpengaruh buruk pada nilai kecernaan protein dan retensi nitrogen.

KataKunci : Broiler, Kepadatankandang, konsumsi protein, kecernaan protein, retensi nitrogen.

\section{ABSTRACT}

This study aims to evaluate broiler chicken protein utilization maintained at high stocking density. The material used in the study was 280 broiler chickens aged 15 days with an average body weight of $298.37 \pm 23.33 \mathrm{~g}$. Complete randomized design (CRD) was used in this study with 4 treatments and 5 replications. The treatment consisted of $T 1=8$ chick $/ \mathrm{m}^{2}, T 2=12 \mathrm{chick} / \mathrm{m}^{2}, T 3=16 \mathrm{chick} / \mathrm{m}^{2}$ and $T 4=20 \mathrm{chick} / \mathrm{m}^{2}$. The research parameters consisted of protein intake, protein digestibility, and nitrogen retention. The results showed that the higher stocking densities significantly recude protein intake $(P<0.05)$ without affecting protein digestibility and nitrogen retention. In conclusions the increase stocking density up to $20 \mathrm{chick} / \mathrm{m}^{2}$ reduce protein intake without adversely affect protein digestibility and nitrogen retention values.

Keywords: Broiler, Stocking density, protein intake, protein digestibility, nitrogen retention. 


\section{PENDAHULUAN}

Ayam broiler merupakan ayam yang dibudidayakan untuk menghasilkan daging dengan kualitas baik. Untuk menunjang hal tersebut dalam pemeliharaan ayam broiler membutuhkan tempat yang nyaman salah satunya yaitu kandang. Kandang merupakan bangunan yang digunakan sebagai tempat tinggal atau tempat makan, minum, berproduksi, berteduh dari cuaca yang beriklim panas, hujan, angin kencang dan gangguan lainnya serta memberikan rasa nyaman bagi ayam (Mulyantini, 2010). Kepadatan ayam dalam kandang bertujuan untuk menjaga agar lingkungan dalam kandang tetap nyaman dan ayam mempunyai ruang yang cukup untuk makan dan minum, sehingga pertumbuhan lebih seragam dan kualitas karkas baik secara optimal dalam pencapaian indek performanya. Tingkat kepadatan ayam yang cukup tinggi dalam kandang akan meningkatkan temperatur lingkungan kandang, ruang untuk ayam dapat makan dan minum menjadi sempit sehingga ayam kesulitan untuk mencapai tempatmakan dan minum, serta kualitas udara dalam kandang pun menjadi menurun. Kondisi ini tentunya menyebabkan ayam jadi mudah mengalami stress dan dapat menurunkan daya tahan tubuhnya terhadap infeksi penyakit serta pertumbuhan ayam menjadi tidak merata (Rasyaf, 2004).

Kepadatan kandang yang semakin tinggi (28 ekor $\left./ \mathrm{m}^{2}-34 \mathrm{ekor} / \mathrm{m}^{2}\right)$ persatuan luas mengakibatkan pertambahan bobot badan yang lebih kecil dan konversi pakan semakin besar (Budiarta et al. 2014). Kepadatan kandang yang tinggi memiliki efek negatif yaitu peningkatan suhu dan kelembaban dalam kandang serta sirkulasi udara yang buruk menyebabkan terjadinya stress pada ayam (Nurfaizin et al. 2014). Stres panas mengakibatkan terjadinya degradasi protein dan menyebabkan radikal bebas sehingga broiler kekurangan nutrisi dan dapat menurunkan produktivitas. Kepadatan kandang yang berlebih dapat mengakibatkan terjadinya persaingan kesempatan makan dan minum serta meningkatnya ekskreta berdampak pada penurunan produktivitas. Walaupun diketahui bahwa kepadatan jumlah ayam dalam kandang dapat menyebabkan stress, di sisi lain efisiensi tempat perlu diperhatikan agar dengan lahan yang dimiliki akan membuat kecernaan protein pada ternak semakin baik.

Kepadatan kandang yang terlalu tinggi berpengaruh terhadap penurunan pada konsumsi ransum, konsumsi protein, dan pemanfaatan protein (Wahju, 2004). Jika ternak tidak memanfaatkan protein yang dikonsumsi maka protein yang berkulitas baik akan menurunkan berat badan. Kepadatan kandang yang tinggi sering menyebabkanternakmenjadikurang nyaman, sulit untuk makan dan minum.

Penelitian ini bertujuan untuk mengevaluasi pemanfaatan protein ransum pada ayam broiler supaya dapat mengoptimalkan konsumsi protein, kecernaan protein, dan retensi nitrogen sehingga berdampak baik untuk pemaanfaatan protein ransum yang dipelihara dalam kandang kepadatan tinggi. Hipotesis dari penelitian ini yaitu terdapat pengaruh kepadatan kandang yang mengakibatkan penurunan konsumsi 
protein tanpa mempengaruhi kecernaan protein dan retensi nitrogen di dalam kecernaan ayam broiler.

\section{MATERI DAN METODE}

Materi yang digunakan dalam penelitian adalah day old chicken(DOC) broiler unsex sebanyak 280 ekor yang dipelihara sampai 42 hari. Ayam broiler dipelihara di kandang sistem terbuka (open house) yang sesuai dengan Standar Operasional Prosedur (SOP) mengikuti standar pemeliharaan. Perlakuan mulai diterapkan pada umur 15 hari dengan bobot badan $298,37 \pm 23,33 \mathrm{~g}(\mathrm{C}=7,81 \%)$. Pada penelitian ini digunakan single feed formulation dengan kandungan nutrisi sebagaimanana tersaji pada Tabel 1.

Tabel 1. Kandungan Nutrien Ransum yang digunakan pada penelitian

\begin{tabular}{|c|c|}
\hline Bahan Pakan & Komposisi (\%) \\
\hline Jagung Kuning & 40,00 \\
\hline Bekatul & 13,00 \\
\hline Bungkil Kedelai & 14,00 \\
\hline Tepung Ikan & 14,00 \\
\hline Meat Bone Meal & 9,00 \\
\hline Poultry Meat Meal & 9,00 \\
\hline Premiks & 1,00 \\
\hline Total & 100,00 \\
\hline 1)Kandungan Nutrisi : & \\
\hline 2)Energi Metabolis (kkal/kg) & $3.296,10$ \\
\hline Protein Kasar (\%) & 23,24 \\
\hline Lemak Kasar (\%) & 7,33 \\
\hline Serat Kasar (\%) & 6,66 \\
\hline Calsium (Ca) & 1,02 \\
\hline Fosfor $(\mathrm{P})$ & 1,10 \\
\hline \multicolumn{2}{|c|}{$\begin{array}{l}\text { Keterangan : } \\
\text { 1)Dianalisis proksimat di Laboratorium Ilmu Nutrisi dan Pakan, Fakultas Peternakan dan } \\
\text { Pertanian, Universitas Diponegoro } \\
\text { 2)Berdasarkan perhitungan rumus Bolton dalam Sugiarto et al. (2017) }\end{array}$} \\
\hline $\begin{array}{l}\text { Rancangan yang digunakan pada } \\
\text { penelitian ini adalah rancangan acak } \\
\text { lengkap (RAL) dengan } 4 \text { perlakuan dan } 5 \\
\text { ulangan. Perlakuan yang diberikan yaitu T1 } \\
\text { = kepadatan kandang } 8 \mathrm{ekor} / \mathrm{m}^{2} \text {, T2 = } \\
\text { kepadatan kandang } 12 \mathrm{ekor} / \mathrm{m}^{2} \text {, T3 = } \\
\text { kepadatan kandang } 16 \mathrm{ekor} / \mathrm{m}^{2} \text { dan T4 = } \\
\text { kepadatan kandang } 20 \mathrm{ekor} / \mathrm{m}^{2} \text {. } \\
\text { Pakan diberikan secara adlibitum } \\
\text { setiap pukul } 06.0012 .0018 .00 \text { dan } 24.00 .\end{array}$ & $\begin{array}{l}\text { Pemanfaatan protein pada penelitian ini } \\
\text { diukur menggunakan parameter berupa } \\
\text { konsumsi protein, kecernaan protein, dan } \\
\text { retensi nitrogen. Pengamatan konsumsi } \\
\text { pakan dilakukan setiap pagi sedangkan } \\
\text { kecernaan protein dan retensi nitrogen } \\
\text { pada akhirpenelitian umur } 42 \text { haridengan } \\
\text { metode total koleksi. Pengukuran suhu dan, } \\
\text { kelembaban lingkungan kandang disajikan } \\
\text { pada Tabel } 2 \text {. }\end{array}$ \\
\hline
\end{tabular}


Tabel2. Nilaisuhu heat stressindex

\begin{tabular}{lrrrr}
\hline \multirow{2}{*}{ Parameter } & \multicolumn{5}{c}{ Perlakuan } \\
\cline { 4 - 5 } Suhu $\left({ }^{\circ} \mathrm{C}\right)$ & 29,1 & $\mathrm{~T} 2$ & $\mathrm{~T} 3$ & $\mathrm{~T}$ \\
$\mathrm{RH}(\%)$ & 67 & 29,2 & 29,4 & 29,7 \\
$\mathrm{HSI}(\%)$ & 151,4 & 151,6 & 66 & 66 \\
\hline
\end{tabular}

Perhitungan konsumsi protein dihitung menggunakan rumus Tillman et al. (1998) sebagai berikut:

Konsumsi protein $(\mathrm{g})=$ konsumsiransum xkadar proteinransum

Kecernaan protein dan retensi nitrogen diukur dengan metode total koleksi. Koleksi ekskreta menggunakan indikator $\mathrm{Fe} 2 \mathrm{O} 3$ sebagai penanda yang dicampurkan dalam pakan perlakuan. Ayam dipilih berdasarkan bobot badan yang seragam kemudian dipuasakan $2 \times 24$ jam dengan tetap diberi air minum. Ekskreta yang telah tertampung kemudian disemprot dengan menggunakan $\mathrm{HCl} 0,2 \mathrm{~N}$ kemudian ekskreta yang terkumpul dibersihkan dari bulu dan pakan yang tercampur kemudian dikeringkan dengan bantuan sinar matahari sampai kering dan dianalisis kandungan nitrogen dan kadar protein. Selanjutnya pakan perlakuan dan ekskreta dianalisis kadar protein kasar (PK) dengan metode Kjedhal.

Kecernaan protein diukur dan dihitung dengan dua tahap yaitu :

1. Analisis Kadar protein = Menganalisis kadar protein yang diekskreta dari pakan untuk mengetahui kecernaan protein yang diukur menggunakan metode Kjedhal.
2. Kecernaan Protein dihitung dengan rumus

Kecernaan protein $(\%) \quad=$

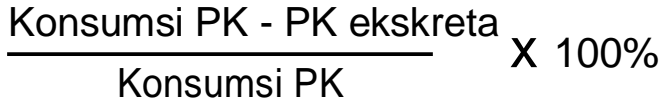

Perhitungan retensi nitrogen adalah untuk mengetahui banyaknya nitrogen yang tertinggal dan dimanfaatkan didalam tubuh. Berdasarkan persamaan Sibbald dan Wolynetz (1985) :

Retensi Nitrogen $(\mathrm{g}) \quad=$ konsumsi N x jumlah N ekskreta

Data yang terkumpul selanjutnya diolah secara statistik dengan analisis ragam (uji F) data yang menunjukan perbedaan nyata diuji lanjut dengan uji wilayah Ganda Ducan.

\section{HASIL DAN PEMBAHASAN}

Konsumsi protein, kecernaan protein dan retensi nitrogen ayam broiler akibat pemeliharaan pada tingkat kepadatan kandang disajikan pada Tabel2. Kepadatan kandang nyata menurunkan konsumsi protein, namun tidak memberikan pengaruh terhadap kecernaan protein, dan retensi nitrogen pada ayam broiler. 
Tabel 3. Konsumsi Protein, Kecernaan Protein dan Retensi Nitrogen Akibat Pengaruh Kepadatan Kandang

\begin{tabular}{lrrrr}
\hline \multirow{2}{*}{ Parameter } & \multicolumn{4}{c}{ Kepadatan Kandang $\left(\mathrm{ekor} / \mathrm{m}^{2}\right)$} \\
\cline { 2 - 5 } & $(8)$ & $(12)$ & $(16)$ & $(20)$ \\
\hline Konsumsi Protein (g/ekor) & $357,70^{\mathrm{a}}$ & $251,45^{\mathrm{b}}$ & $207,01^{\mathrm{c}}$ & $164,71^{\mathrm{d}}$ \\
Kecernaan Protein(\%) & 82,85 & 86,47 & 88,55 & 85,93 \\
Retensi Nitrogen $(\mathrm{g})$ & 3,85 & 4,05 & 5,29 & 4,78 \\
\hline Superskrip berbeda pada baris yang sama menunjukan perbedaan nyata $(\mathrm{P}<0,05)$
\end{tabular}

\section{Konsumsi Protein}

Pada tabel diatas menjadikan bahwa. Semakin tinggi kepadatan kandang maka akan berpengaruh pada semakin rendah rasio feeder dan drinker terhadap konsumsi protein. Hal ini berdampakpada Peluang makan sehingga kesempatan mengkonsumsi pakan menjadi berkurang.
Berkurangnya peluang makan akan berdampak pada penurunan konsumsi protein Wahyu (1984) menjelaskan konsumsi akan meningkat bila diberi ransum yang berenergi rendah dan menurun bila diberi ransum yang berenergi tinggi.

Tabel4. Rasio Luas TempatPakandanLuas Tempat MinumterhadapJumlah Ayam

\begin{tabular}{crr}
\hline $\begin{array}{c}\text { Kepadatan } \\
\text { ekor/m }\end{array}$ & $\begin{array}{r}\text { Rasio feeder } \\
\mathrm{cm}^{2} / \text { ekor }\end{array}$ & $\begin{array}{r}\text { Rasio drinker } \\
\mathrm{cm}^{2} / \text { ekor }\end{array}$ \\
\hline 8 & 36,11 & 46,70 \\
12 & 24,07 & 31,13 \\
16 & 18,05 & 23,35 \\
20 & 14,44 & 18,68 \\
\hline
\end{tabular}

Penurunan konsumsi protein tersebut terjadi karena tingkat kepadatan kandang yang tinggi diatas $8 \mathrm{ekor} / \mathrm{m} 2(12,16$ dan 20) mengakibatkan konsumsi ransum menurun. Hal tersebut sesuai dengan penelitian Kuan et al. (1990) bahwa ayam broiler dengan kepadatan kandang 8, 10 dan $12 \mathrm{ekor} / \mathrm{m} 2$ menunjukkan hasil yang berbeda pada setiap kandang terhadap konsumsi ransum. Kepadatan kandang yang rendah, ayam cenderung lebih aktif dan mengkonsumsi ransum lebih banyak daripada ayam dengan kepadatan kandang yang tinggi. Kepadatan kandang yang tinggi cenderung menyebabkan ayam menjadi kurang aktif dalam tingkah laku di kandang sehingga memungkinkan ayam mengurangi konsumsi ransum untuk meminimalkan panas tubuh. Penurunan konsumsi ransum akan berdampak pada penurunan konsumsi protein karena jumlah konsumsi protein berbanding lurus dengan konsumsi ransum. Gultom (2014) menyatakan bahwa konsumsi protein dipengaruhi oleh konsumsi ransum sehingga konsumsi ransum yang baik akan menujukan konsumsi protein yang baik pula. Penurunan konsumsi protein dapat pula disebabkan oleh cekaman pada ayamakibat kepadatan kandang.

Cekaman tersebut disebabkan suhu didalam kandang menjadi naik karena 
panas yang dihasilkan ayam dalam proses metabolisme. Selain itu menyebabkan ruang geraknya menjadi terbatas dan menimbulkan ketidaknyamanan pada ayam. Iskandar et al. (2009) menyatakan bahwa ketidak-nyamanan ruang gerak menyebabkan ayam menurunkan konsumsi ransum. Pada penelitian ini terdapat peningkatan suhu $27-29{ }^{\circ} \mathrm{C}$ akibat peningkatan kepadatan maka konsumsi mengalami penurunan pada T2,T3 dan T4 yang berdampak pada penurunan konsumsi pakan dan diikuti dengan penurunan konsumsi protein.

\section{Kecernaan Protein}

Pada penelitian yang kami lakukan tidak ada pengaruh nyata pada kecernaan protein terhadap kepadatan kandang. Hal ini diduga meskipun kecernaan protein menurun namun belum memberikan dampak terhadap kecernaan protein pada ayam yang dipelihara dengan kepadatan rendah lebih tinggi daripada kepadatan tinggi karena ayam pada kepadatan rendah tidak mengalami stress panas.

Peningkatan peluang terjadinya stress panas pada kepadatan kandang dipicu oleh rendahnya nilai HSI (heat stress indeks) kondisi lingkungan yang berkisar antara 27$29^{\circ} \mathrm{C}$ maka beban panas dalam tubuh ayam menjadi lebih besarkarena suhu lingkungan tersebut menyebabkan ayam akan mengalami cekaman panas tetapi masi berada pada level stress rendah biasanya ayam cenderung banyak minum dan sedikit mengkonsumsi pakan. Suprijatna et al. (2005) menyatakan bahwa ayam mengalami cekaman panas akibat tingginya suhu lingkungan dan panas yang dihasilkan oleh proses pencernaan dan banyaknya protein yang dibuang bersama ekskreta, semakin sedikit protein yang dibuang bersama feses makan akan meningkatkan nilai kecernaan.

Beban panas yang berlebih ini menyebabkan ayam mengalami cekaman panas, sehingga akan menurunkan efisiensi terhadap proses pencernaan, absorpsi dan transport nutrient. Menurut (Prawitasari, 2012).

\section{Retensi Nitrogen}

Penelitian yang kami lakukan tidak ada pengaruh nyata pada retensi nitrogen terhadap kepadatan kandang. Pada penelitian ini menunjukan bahwa pada retensi nitrogen menyebabkan ayam mengalami cekaman panas tetapi masi berada pada level stress rendah dikarenakan masih berada di suhu lingkungan kondisi ideal yaitu antara (22$24^{\circ} \mathrm{C}$ ) yang memiliki nilai HSI (heat stress indeks) menurun pada tingkat kepadatan berbeda ternyata tidak menunjukkan perbedaan yang besar (lihat tabel), sehingga tidak sampai mempengaruhi Retensi Nitrogen secara nyata. Salah satu upaya yang dilakukan ayam untuk mempertahankan suhu tubuhnya akibat sress dengan mengurangi konsumsi pakan. Menurut kusnadi (2004) bahwa ayam broiler yang mengalami stress panas akan cenderung mengurangi konsumsi pakan koversi pakan dan meningkatkan konsumsi air minum.

Selain kenaikan suhu lingkungan konsentrasi amoniak dapat menjadi faktor lain penurunan konsumsi pakan. Meningkatnya konsentrasi amoniak 
menyebabkan amoniak yang terhirup oleh ayam sehingga makin tinggi sehingga asupan ransum yang dicerna berkurang. Retensinitrogen dipengaruhioleh beberapa faktor yaitu konsumsi ransum, konsumsi protein dan kualitas protein, semakin tinggi konsumsi ransum maka retensi nitrogen akan semakin tinggi pula. Wahju (2004) menyatakan bahwa meningkatnya konsumsi ransum akan memberikan kesempatan kepada tubuh untuk meretensi lebih banyak makanan sehingga kebutuhan protein untuk pertumbuhan terpenuhi.

\section{SIMPULAN}

Berdasarkan hasil penelitian dapat disimpulkan bahwa peningkatan kepadatan kandang tinggi dapat menurunkan konsumsi protein tetapi tanpa mempengaruhi nilai kecernaan protein dan retensi nitrogen.

\section{DAFTAR PUSTAKA}

Budiarta, D. H, E. Sudjarwo, dan N. Cholis. 2014. Pengaruh kepadatan kandang terhadap konsumsi pakan, pertambahan bobot badan dan konversi pakan pada ayam pedaging. Jurnal Ternak Tropika. 2:31-35.

Gultom,S.M., Supratman, R.D.H., Abun., 2014. Pengaruh Imbangan Energi dan Protein Ransum Terhadap Bobot karkas dan bobot lemak abdominal ayam broiler umur 3-5 minggu. Jurnal Fakultas Peternakan, Universitas Padjajaran, Bandung.

Iskandar, S. 2009. Pertumbuhan Ayam Lokal sampai dengan Umur 12 Minggu pada Pemeliharaan Intensif. Balai Penelitian Ternak Ciawi. Bogor.

Kuan, K.K., S. Adnan, and H. Ramlah. 1990. Effect of Increasing Stocking Density on Performance and Heterophil/lymphocyte Ratio in Broilers. Pertanika 13(2): 171-175.

Kusnadi, E. 2004. Pegaruh pemberian pegagan(Centella asiatica) terhadap respon ayam broiler yang dipelihara pada suhu lingkungan yang berbeda. Jurnal Peternakan dan Lingkungan 10: 10-14.

Mulyantini, N. G. A. 2010. IImu Manajemen Ternak Unggas. Gadjah Mada University Press. Yogyakarta. Halaman 4-35.

Nurfaizin, L. D. Mahfudz dan U. Atmomarsono. 2014. Profil hematologi ayam broiler akibat pemeliharaan dengan kepadatan kandang dan penambahan jintan hitam (Nigella setiva) yang berbeda. Jurnal Agromedia. 32 (1):81-88.

Prawitasari. R.H., Yunianto.V.D dan Estiningdriati.I. 2012. Kecernaan Protein Kasar Dan Serat Kasar Serta Laju Digesta Pada Ayam Arab Yang Diberi Ransum Dengan Berbagai Level Azolla Microphylla. Anim Agric. J. 1 (1):471-483.

Rasyaf. 2004. Beternak Ayam Pedaging. Cetakan 25. Kanisius. Yogyakarta.

Sibbald, I. R. and M. S. Wolynetz. 1985. Estimates of retained nitrogen used to correct estimates of bioavailable energy.Poult. Sci.64:1506-1513.

Sugiharto, S., T. Yudiarti and I. Isroli. 2017.Effects Of Feeding Cassava Pulp Fermented With Acremonium 
Charticola On Growth Performance, Nutrient Digestibility And Meat Quality Of Broiler Chicks.Journal of Animal Science, South African. Vol 47 (2): 130-138.

Suprijatna, E., U. Atmomarsono, dan R. Kartasudjana. 2005. Ilmu Dasar Ternak Unggas. Penebar Swadaya, Jakarta.

Tillman, A. D., H. Hartadi, S. Reksohadiprodjo, S. Prawiro
Kusuma, dan S. Lebdosoekoekojo. 1998. IImu Makanan Ternak Dasar. Gadjah Mada University Press, Yogyakarta.

Wahju, J. 2004. Ilmu Nutrisi Unggas. Gadjah Mada University Press, Yogyakarta.

Wahyu, J. 1984. Penuntun Praktis Beternak Ayam. Cetakan ke-4, Fakultas Peternakan Institut Pertanian Bogor. Bogor. 